\section{In Camera Review}

\author{
Robert L. Heilbronner \\ Chicago Neuropsychology Group, Chicago, IL, \\ USA
}

\section{Definition}

In camera is a Latin term meaning "in chambers." It refers to a hearing or discussions with the judge in the privacy of his/her chambers (office rooms) or when spectators and jurors have been excluded from the courtroom. An in camera examination may be made of confidential or sensitive information (e.g., raw test data) to determine whether to introduce it to the jury and make it part of public record. An in camera hearing can be either on or off the record, though they are usually recorded. In camera hearings are often held to shield a jury from any potential bias caused by controversial matters, or to protect the privacy of the people involved, and are common in cases of guardianships, personal injury, medical malpractice, adoptions, and custody disputes alleging child abuse. In forensic neuropsychology, in camera reviews most often take place in response to a neuropsychologist's duty/request to protect the security of the raw test data. He/she makes a request that the judge perform an in camera review of the data so that the materials do not get distributed to non-psychologists (e.g., attorneys, jury members).

\section{Cross-References}

- Confidentiality

- Independent Examination

\section{References and Readings}

American Psychological Association. (2002). Ethical principles of psychologists and code of conduct. American Psychologist, 57, 1048-1051.

Bush, S. S., \& The NAN Policy \& Planning Committee. (2005). Independent and court-ordered forensic neuropsychological examinations: Official statement of the National Academy of neuropsychology. Archives of Clinical Neuropsychology, 20, 997-1007.

Committee on Legal Issues, American Psychological Association. (2006). Strategies for private practitioners coping with subpoenas or compelled testimony for client records or test data. Professional Psychology: Research and Practice, 37, 215-222. 